OPEN ACCESS

Edited by:

Hans J. ten Donkelaar, Radboud University Nijmegen,

Netherlands

Reviewed by:

Robert Joel Ruben,

Montefiore Medical Center,

United States

Robert H. Baud,

Université de Fribourg, Switzerland

*Correspondence.

Bernd Fritzsch

bernd-fritzsch@uiowa.edu

Received: 27 July 2018 Accepted: 05 November 2018

Published: 23 November 2018

Citation:

Fritzsch B and Elliott KL (2018) Auditory Nomenclature: Combining

Name Recognition With Anatomical Description. Front. Neuroanat. 12:99.

doi: 10.3389/fnana.2018.00099

\section{Auditory Nomenclature: Combining Name Recognition With Anatomical Description}

\author{
Bernd Fritzsch* and Karen L. Elliott \\ Department of Biology, The University of lowa, lowa City, IA, United States
}

The inner ear and its two subsystems, the vestibular and the auditory system, exemplify how the identification of distinct cellular or anatomical elements ahead of elucidating their function, leads to a medley of anatomically defined and recognition oriented names that confused generations of students. Past attempts to clarify this unyielding nomenclature had incomplete success, as they could not yet generate an explanatory nomenclature. Building on these past efforts, we propose a somewhat revised nomenclature that keeps most of the past nomenclature as proposed and follows a simple rule: Anatomical and explanatory terms are combined followed, in brackets, by the name of the discoverer (see Table 1). For example, the "organ of Corti" will turn into the spiral auditory organ (of Corti). This revised nomenclature build as much as possible on existing terms that have explanatory value while keeping the recognition of discoverers alive to allow a transition for those used to the eponyms. Once implements, the proposed terminology should help future generations in learning the structure-function correlates of the ear more easily. To facilitate future understanding, leading genetic identifiers for a given structure have been added wherever possible.

Keywords: ear, development, sensory epithelia, sensory neurons, auditory nuclei

\section{INTRODUCTION}

The ear was recognized as the organ for hearing since antiquity, but its function could only be understood mechanistically after Corti (1851) described some of the cells on the basilar membrane of what Kölliker soon referred to as the organ of Corti (Kölliker, 1852, 1867). Nearly overlapping in time, Reissner (1851) described the membrane separating the scala media from the scala vestibuli, now bearing his name (Reissner's membrane) to identify three distinct channels in the cochlear canal instead of two as previously identified based on ever improving anatomical work. With the event of better preservation, decalcification and histological sections, many new features were discovered in the second half of 19th century. Naming those novel ear structures in the 1850-70 time frame continued a tradition of eponyms that dates back to Falloppio's canal [now known as facial nerve canal (Politzer, 1907, 1981)] and followed the rational that names of first identifiers were associated with the structure they identified (Claudius, 1856; Boettcher, 1859; Hensen, 1863). Since discovery of new cell types outpaced for many years any reasonable understanding of their function, this approach was the most logical way forward to avoid over speculating on unclear function. In parallel to anatomical discoveries, functional ideas were proposed by Willis (1672). He believed that sound enters with movement of the stapes footplate through the oval window, is reflected and amplified in the semicircular canals before it is received by the "acoustic nerve" 
in the cochlea. Duverney (1730) noticed the different diameters of the cochlea duct and used his anatomical insights to invoke a resonance theory of hearing only much later elaborated on by Helmholtz (1859) and ultimately demonstrated as tonotopic organization of the cochlea by Békésy (1930). Neither name is in any way associated with their insights as eponyms, emphasizing the lopsided distribution of credit given by the somewhat random use of eponyms.

For example, it was only in 1789 that Scarpa (1800) surpassed the detailed description of Duverney (1730) and fully described the membranous labyrinth of the inner ear. And yet Scarpa's name is only used as an eponym of the vestibular (or Scarpa's ganglion; Table 1). The excellent illustrative work of von Sömmering (1806) which laid the foundation of much of the histology and comparative work of the 19th century, including the comparative work of Retzius $(1881,1884)$ never earned him any eponym. Even Retzius' name was not associated with the amphibian papilla he described but is only associated with the Retzius' bodies in the outer hair cells (Lim, 1986). After the foundation of the histology of the mammalian organ of Corti was established, details that were added later through more refined histological analysis did not earn eponyms such the newly described border cells for Held (1902, 1926). This contrasts sharply with the fact that Held's earlier description of large contacts in brainstem auditory nuclei are now known under the eponym "endbulbs" and "calyx" of Held (1893).

Many years of continued insight into the cellular and subcellular details of the organ of Corti, organization and function allow now to go beyond the purely descriptive and initially disputed original work. Today, the entrenched use of eponyms in otolaryngology confuses students and blocks understanding through enforced learning of eponyms that have no meaning beyond honoring the original descriptor and conserve an anatomical terminology that is in part unrelated to the function that was mostly unclear at the time the structures were first described. Eponyms were less fashionable from 1880 to today, novel features nevertheless received trivial names that do not convey the level of understanding detailed anatomy, physiology and molecular development of the ear now allows. Inconsistencies abound, such as the inner border cells [Grenzzelle (Held, 1902)] are not called Held's cells whereas the outer border cells are now referred to as Hensen's (1863) cells . Likewise, the outer phalangeal cells are now mostly referred to as Deiters (1860) cells whereas the inner phalangeal cells have no eponym. Complicating cochlear nomenclature even further, some trivial names are redundant and confusing such as type 1 and 2 hair cells in the vestibular system and Type I and II spiral ganglion neurons in the cochlea, evoking false associations in students new to the ear nomenclature. And some names were differently translated such as the German "Pfeilerzelle" is now referred to in US English as "pillar cells" but in United Kingdom English as "pilar cells," with only the former presenting a translation according to the German meaning. Some of these issues have been partially rectified by taking traditional/scientific terms, multilingual discrepancies, role of Latin terms, usage of adjectives vs. genitive, usage of poorly defined words, usage of eponyms into account in previous nomenclature revisions (FCOA, 1998;
FIPAT, 2017). The motivation for the present revision is to build on these past considerations reflected in the most recently proposed nomenclature (Table 1) while taking a more novel molecular and functional considerations into account.

Obviously, eponyms avoided associating mistaken functions to various parts of the ear (Politzer, 1907, 1981; Lustig et al., 1998; Mudry, 2001) and isolated the morphological description from functional speculations, certainly an important consideration at a time when vestibular and auditory function of the ear were mostly unknown and in many cases simply misinterpreted. Adding to this confusion in the more recent literature were mistranslations [the border cells of Held are now mostly referred to as "inner border cells" (Held, 1902) due to a mistake in one summary image] that identified what appears to be the same cell by different names. It was only later that hearing and vestibular function could be associated with different parts of the ear through the works of Mach (1865a,b), Breuer (1873), Barany (1906), Békésy (1930) and Helmholtz (1859). Both the function of the ear as a gravistatic and angular motion detection system and the function of the cochlea as a frequency and intensity monitoring system have been clarified as distinct functions of the mammalian ear (Hudspeth, 1989). The detailed understanding of the organ of Corti was advanced by modern techniques beyond the excellent description of Held $(1902,1926)$ using electron microscopy, summarized by Lim (1986) and Slepecky (1996) and quantitative ratios of different cell types of the organ of Corti (Jahan et al., 2015). We now know that hair cells function as polarized mechanotransducers (Hudspeth, 1989) with a distinctly different function of the inner and outer hair cells in amplification and reception of sound (Zheng et al., 2000). For example, sound stimulation of the organ of Corti was long been depicted as a simple up-down movement that directly caused shearing forces of the tectorial membrane on the inner hair cell stereocilia (Lewis et al., 1985). In contrast, more recent work suggest that the adult inner hair cell is not connected to the tectorial membrane (Lim, 1986) but acts as a hydrodynamic receptor monitoring endolymph flow in and out of the subtectorial space (Elliott et al., 2018).

More recent work on early development using gene expression and functional assessments of afferent, efferent, and hair cell proteins provides novel ways of identifying cells of the ear not only based on their topology and function but on their molecular signature (Liu et al., 2014). Unsurprisingly, such molecular data open again issues of identification of cell types and regrouping previous anatomical distinctions into smaller subgroups. For example, spiral ganglion neurons were initially described as homogenous (Corti, 1851) or as multiple types (De No, 1981), regrouped eventually into just two types based on diameters and innervation (Spoendlin, 1971), but subsequently again expanded to three types based on physiological properties (Merchan-Perez and Liberman, 1996; Rutherford and Moser, 2016). The latter suggestions are now supported by their molecular signatures (Petitpré et al., 2018; Shrestha et al., 2018; Sun et al., 2018). While all papers agree on the major expression they use inconsistent, albeit similar nomenclature: for example, what is Type Ia in two papers (Shrestha et al., 2018; Sun et al., 2018) is Type Ic in the third paper (Petitpré et al., 2018). The solution to this 
TABLE 1 | Terminology for the inner ear.

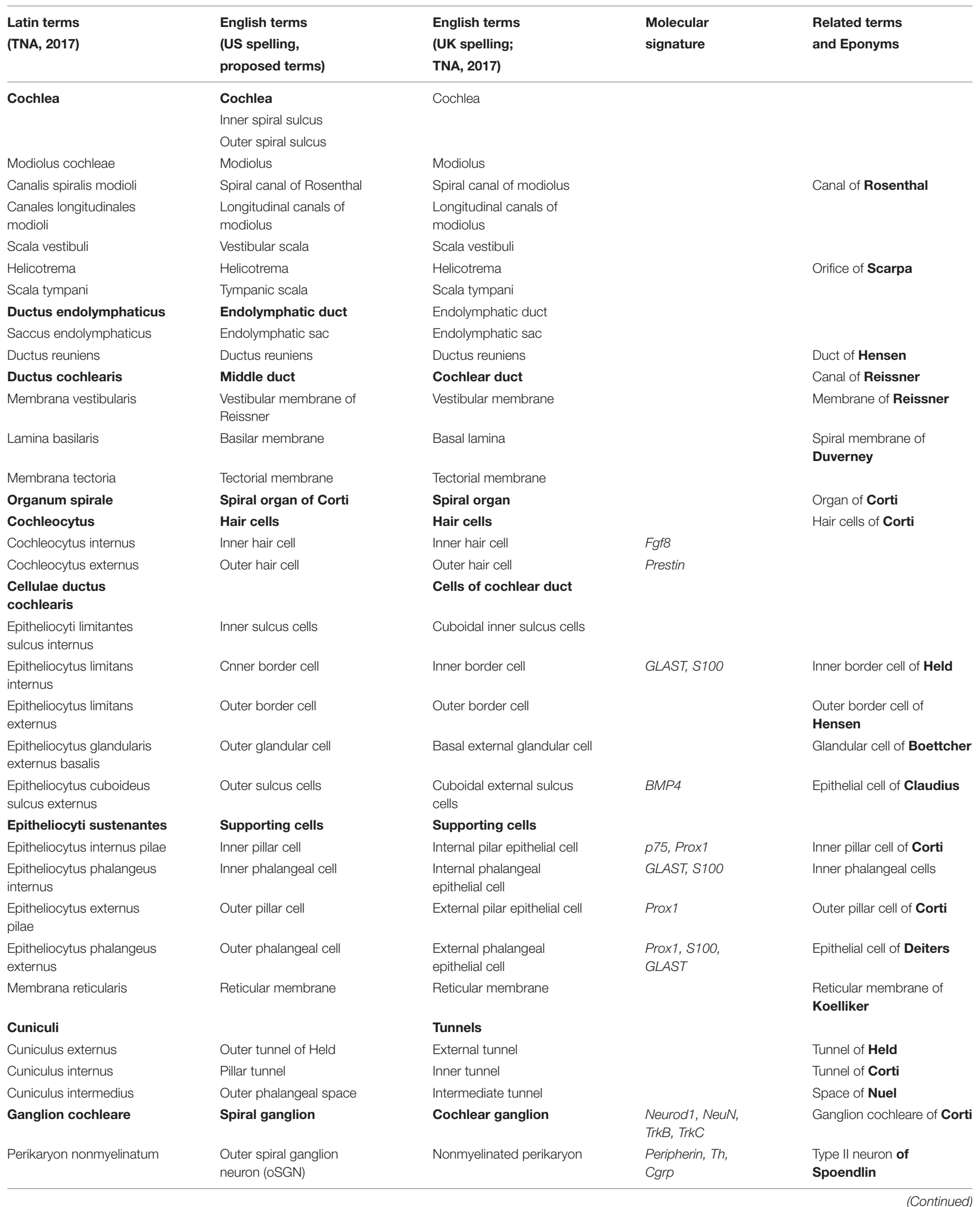


TABLE 1 | Continued

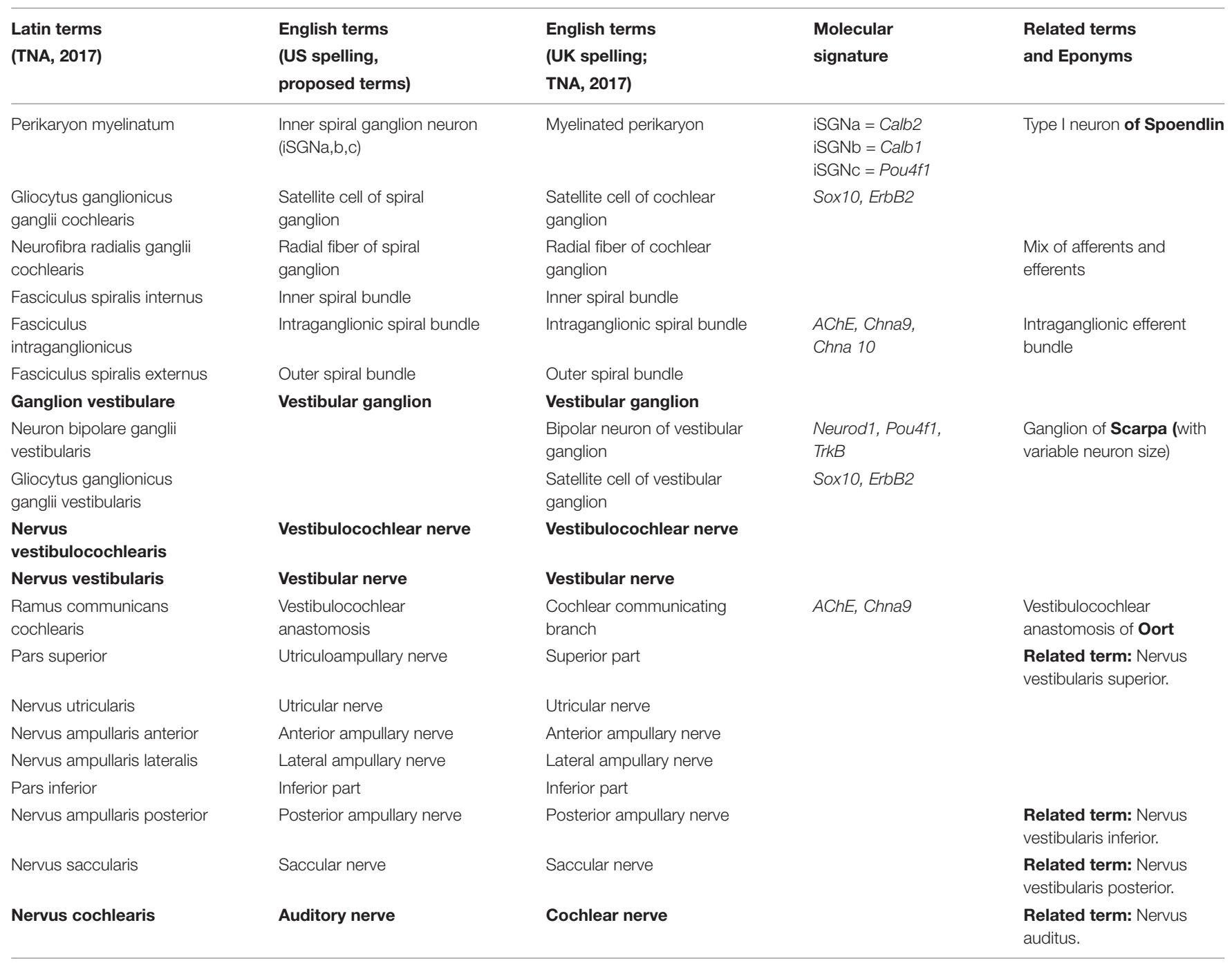

This table was modified after (FCOA, 1998; FIPAT, 2017).

emerging nomenclature problem is to adopt a more meaningful nomenclature such as inner Spiral Ganglion Neurons, subtype a (iSGNa) as proposed in Table 1. It is to be expected that further single cell sequencing will likely lead to subdivisions of vestibular ganglion neurons as well given their cellular heterogeneity.

While some genes such as Sox 2 are associated early in development with all neurosensory cells of the ear, they later become restricted to supporting cells following upregulation of high levels of Atoh1 in hair cells (Dabdoub et al., 2008). Interestingly enough, such gene expression over time depends on the level of expression of other transcription factors, as inner pillar cells show only limited expression of Atoh1 that does not affect Sox2 expression (Matei et al., 2005). Thus, while anatomical features and their physiological implications are largely settled, molecular signatures are still in flux due to technical advances that permit cell specific expression profile assessment to understand the complex cell type development and maintenance (Booth et al., 2018) as well as the gene expression profiles leading to specific structures such a stereocilia development
(Ellwanger et al., 2018). Past research has stepwise improved the understanding of how sound moves the basilar membrane/organ of Corti/tectorial membrane complex to provide topology specific amplification (Ren et al., 2016; Dewey et al., 2018), including a detailed understanding of the function of the cochlear amplifier in the three rows of outer hair cells (Xia et al., 2018). Increasingly detailed insights into the function of the various sections of the organ of Corti have revealed major distinctions as an outer section playing a role in sound amplification and an inner section playing a role in sound conversion (Elliott et al., 2018). Molecular signatures that highlight nearly all outer section cells, including the inner pillar cells, such as Prox1, have been described (Fritzsch et al., 2010) that set the organ of Corti apart from vestibular sensory epithelia (Bermingham-McDonogh et al., 2006). Other transcription factors are uniquely found in a single cell type of the organ of Corti such as Fgf8 in inner hair cells that is found in many vestibular hair cells (Jahan et al., 2018) or the p75 neurotrophin receptor in inner pillar cells but also in sensory neurons (Von Bartheld et al., 1991). As more single cell 


\section{A}

\section{Spiral organ (of Corti)}

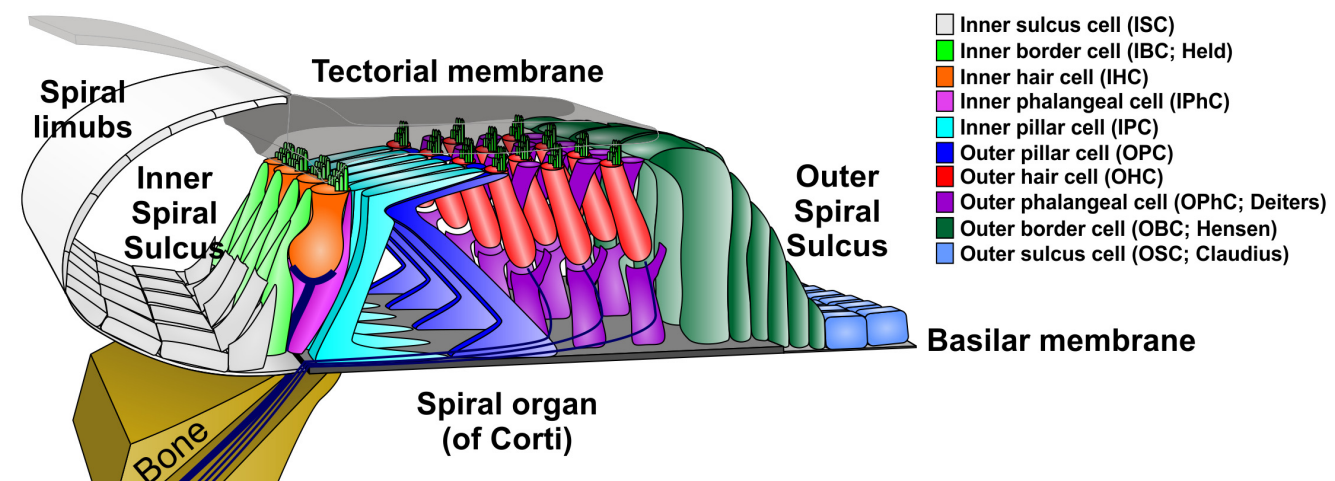

Spiral canal

(of Rosenthal)

8

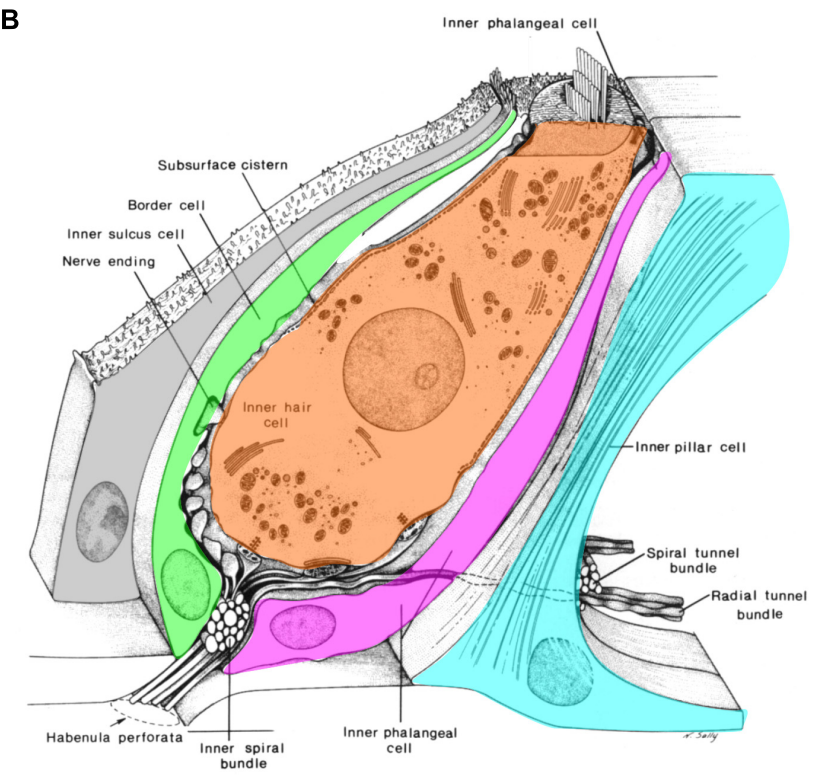

C

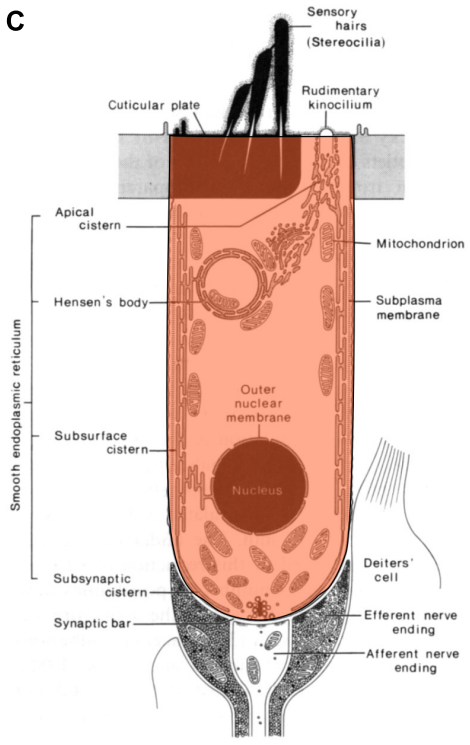

FIGURE 1 | The cellular organization of the organ of Corti is shown in a radial section (A) and the details of the inner hair cell (B) and outer hair cell (C) as revealed by transmission electron microscopy. Radial sections suggest a simple numerical relationship of cells of the inner section (1IBC, $1 \mathrm{IHC}, 1 \mathrm{IPhC}, 1 \mathrm{IPC}$ ) and other section (1OPC, $3 \mathrm{OHC}, 3 \mathrm{OPhC}, 3+\mathrm{OBC}$ ). Note that the inner pillar cell (IPC) sits on the bony lip of the spiral canal (of Rosenthal). Equivalent cells of the outer and inner section are in different shades of the same color. Modified after Elliott et al. (2018) and Lim (1986).

transcriptome analyses are published, the current insights will likely be supplemented by both better characterization of unique expression profiles but will likely also end up indicating that some specificity is only a matter of thresholds of detection inherent to applied techniques.

\section{GOALS OF THE PROPOSED REVISION}

With this caveat of some future refinement based on deeper molecular understanding in mind, we propose here a revision of the most recent nomenclature (FCOA, 1998; FIPAT, 2017) that primarily builds on topology, physiology and, wherever possible, unique molecular signature (Figures 1, 2 and Table 1), taken ultrastructural details and their functional significance revealed over the last 70 years into account (Engström et al., 1964; Kimura, 1975; Lim, 1986; Slepecky, 1996). We propose to divide the spiral auditory organ (of Corti) into an inner and an outer section with appropriate expansion of the existing nomenclature to name each element accordingly:

The inner section is the sound receiving section. We propose to expand the already partially consistent nomenclature (inner spiral sulcus, inner hair cell, inner pillar cell, inner phalangeal cells (FCOA, 1998; FIPAT, 2017)) that excludes 

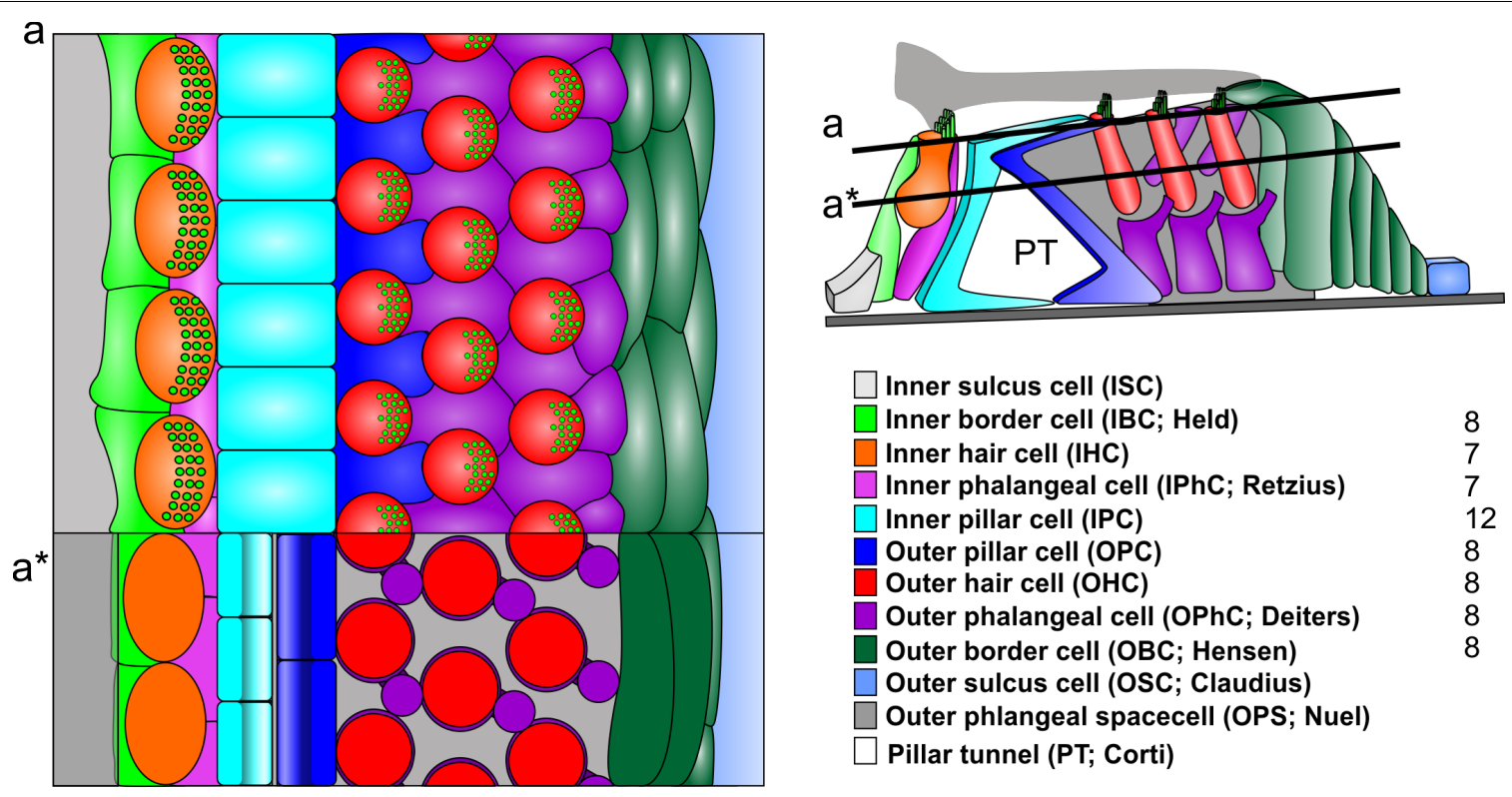

FIGURE 2 | In contrast to radial sections, top views on the reticular lamina (a) or horizontal sections below the reticular lamina (a*) indicate a different numerical ration between the cells of the inner section and outer section (right). Note that the largest number of cells are the ilPC with no clear numeric ratio to any of the adjacent cells. Note that the outer section has a simple 1:1 ratio between all elements of a given row also the details of most cells differ. For example, the reticular lamina is formed by the out rudder of the OPC between the first row of $\mathrm{OHC}$ (blue) but by the $1+2$ second rows of OPhCs between the $2+3$ row of OHC. The third row of OPhCs forms a continuous boundary along the reticular lamina flanking OBCs. IHC are in direct contact to IPCs only at the reticular lamina (a) whereas they are in contact with each other below the reticular lamina and are completely separated from IPC by the IPhC. Modified after Jahan et al. (2015).

some other relevant features. For example, it is now clear that the two major types of spiral ganglion neurons, type I and II, innervate the inner and outer hair cells, respectively. We therefore propose to use a new nomenclature of inner spiral ganglion neuron and outer spiral ganglion neuron instead of type I and type II. With the exception of transient expansion of some inner spiral neurons into the outer section during development (Druckenbrod and Goodrich, 2015; Goodrich, 2016) and under certain conditions of hair cell disorganization (Jahan et al., 2018), these neuronal processes of type 1 spiral ganglion neurons remain within the inner section and are named inner spiral ganglion neurons. Beyond possible transient developmental expansions to outer hair cells, the so-called lateral olivo-cochlear (LOC) system of inner ear efferents (Simmons et al., 2011) remains also restricted to the inner section and should thus be referred to as the inner (olivo-cochlear) efferents. Past use was also inconsistent with respect to (inner) border cells, dating back to the original description of this cell (Held, 1902) and extending into more detailed histology (Lim, 1986; Slepecky, 1996). We propose to use inner border cells to highlight these transitional cell type from the inner sulcus cells and propose to use the term outer border cells for the transitional cell type to outer sulcus cells, both with appropriate eponyms [inner border cells (of Held), outer border cells (of Hensen)].

The outer section is the sound amplifying section. The nomenclature of this section is less consistent overall (FCOA, 1998; FIPAT, 2017). The outer pillar cells (of Corti) and outer sulcus cells (of Claudius) are in the existing nomenclature as well as outer phalangeal cells (of Deiters). Neither the Hensen cells (here referred to as outer border cells of Hensen) nor the Boettcher cells (restricted to the basal turn) have been included into a consistent nomenclature. As with the inner section, both afferent and efferent innervation can be renamed to reflect their exclusive projection to outer hair cells in the adult organ (Rubel and Fritzsch, 2002; Goodrich, 2016). With this exclusive connection in normal adult mammals in mind, type II spiral ganglion neurons should be renamed as outer spiral ganglion neurons. Likewise, the clear exclusive connection of the medial olivo-cochlear neurons to outer hair cells (Simmons et al., 2011) necessitates to rename them as outer (olivo-cochlear) efferents. Note that this nomenclature proposal for afferent and efferent neurons reflects to terminals in spiral auditory organ (of Corti) and not the distribution of their cell bodies near the superior olivary complex as in the past.

Adopting this nomenclature would help to entrench the functional differences of the two sections in the context of their topology: the inner section is the "hearing" section that has all the inner hair cells with associated inner supporting cells, inner afferents and inner efferents needed for hearing. In contrast, the outer section is the "amplifier" section with the contractile outer hair cells innervated predominantly by the outer efferents with outer spiral afferents playing a role only in very loud sound hearing related to damage (Liu et al., 2015). Both sections are mirror symmetric with respect to cell type distribution.

The inner section cell types progresses from medial (modiolar) to lateral as follows: inner sulcus cells (ISC), inner 
border cells (IBC), inner hair cells (IHC), inner phalangeal cells (IPhC), inner pillar cells IPC (Figure 1).

The outer section cell types progresses (in reverse cellular order) from lateral to medial as follows: outer sulcus cells (OSC), outer border cells (OBC), outer hair cells (OHC), outer phalangeal cells (OPhC), and outer pillar cells (OPC; Figure 1). The pillar tunnel (of Corti) divides the numerical and organizationally distinct (Jahan et al., 2015) inner and outer section.

While the two sections have similar overall numbers of cell types (excluding the basal outer border cells [of Boettcher] in the apex, the total numbers of cellular units to each section vary dramatically. For example, the inner section receives the vast majority of afferents $(\sim 95 \%)$ and efferents $(\sim 60 \%)$ but has overall fewer units of each cell type in a radial section (one IBC as compared to 2-4 OBC, one IPhC as compared to three OPhC, one IHC compared to three OHC [except for reduced numbers in the base and increased numbers in the apex]. The only symmetry in terms of numbers of elements are IPC and OPC. However, this apparent symmetry even of these cells is a consequence of the radial section perspective (Figure 1). Viewed from the reticular lamina, the OHC and OphC/OPC form a nearly perfectly alternating cellular network (Figure 2). In contrast, near the basal lamina, all supporting cells in the outer section are in broad contact with each other without any outer hair cell in between. Interestingly enough, while IPC and OPC are in broad contact both basally and apically (Lim, 1986; Slepecky, 1996), the numbers of IPC and OPC cells are in a 3:2 ratio (Held, 1902). Whereas OHC are never in contact with each other, IHC are in very broad contact with each other being separated only at the reticular lamina by the IPhC and IBC [Lim, 1986; Held, 1902; Slepecky, 1996] and touching only at the reticular lamina the IPC (Figures 1, 2). Thus, while lateral inhibition with the delta-notch interaction may explain the formation of the outer section mosaic it fails to explain the inner section cell assembly. In fact, the real numerical relationship of each cell type for a given stretch of the

\section{REFERENCES}

FCOA (1998). Terminology, Terminologia Anatomica. London: Georg Thieme Verlag.

Barany, R. (1906). Untersuchungen über den vom Vestibularapparat des Ohres Reflektorisch Ausgelösten Rhythmischen Nystagmus und seine Begleiterscheinungen. Washington, DC: Oscar Coblentz.

Békésy, G. V. (1930). Uber das Fechnersche Gesetz und seine Bedeutung für die Theorie der akustischen Beobachtungsfehler und die Theorie des Hörens. Annalen der Physik 399, 329-359. doi: 10.1002/andp.1930399 0305

Bermingham-McDonogh, O., Oesterle, E. C., Stone, J. S., Hume, C. R., Huynh, H. M., and Hayashi, T. (2006). Expression of Proxl during mouse cochlear development. J. Comp. Neurol. 496, 172-186. doi: 10.1002/cne.20944

Boettcher, A. (1859). Weitere beiträge zur anatomie der schnecke. Arch. Pathol. Anatom. Physiol. klinische Med. 17, 243-281.

Booth, K. T., Azaiez, H. R., Smith, J. H., Jahan, I., and Fritzsch, B. (2018). Intracellular regulome variability along the organ of Corti: evidence, approaches, challenges and perspective. Front. Genet. 9:156. doi: 10.3389/fgene. 2018.00156

Breuer, J. (1873). Ueber die Bogengänge des Labyrinths. Allgemeine Wiener Med. Zeitung 18, 598. spiral auditory organ (of Corti) for humans is: $\mathrm{IBC}=8$; IHC $=7$; $\mathrm{IPhC}=7 ; \mathrm{IP}=12 ; \mathrm{OP}=8 ; \mathrm{IHC}=8 \times 3$ rows $\mathrm{OPhC}=8 \times 3$ rows; $\mathrm{OBC}=8 \times 3-4$ rows (Jahan et al., 2015).

While some of these odd numerical relationships have been known since Retzius (1884) and Held (1902) counted them, their implication for developmental biology in terms of regulating their differential numbers has been nearly universally ignored. Various studies have revealed that this ratio is extremely dependent on diffusible factors and cell-cell interactions (Groves and Fekete, 2012, 2017; Jahan et al., 2018). More recent emphasis on effects of gene replacement on these cellular numeric ratios and their distribution have re-emphasized these differences between the two sections that need to be understood for any forward looking strategy to restore a functional spiral auditory organ (of Corti) and thus hearing from a flat epithelium (Jahan et al., 2018). Restoring an outer section will certainly not restore hearing but an inner section associated with proper amplification might be beneficial to maintain most afferent innervation through neurotrophic support (Fritzsch et al., 2016) and might be useful for hearing with proper amplification to offset the loss of the outer section. Overall, our proposal takes much of the existing nomenclature (FCOA, 1998; FIPAT, 2017) into account but provides a more uniform description of cellular elements around the now understood functional sections of the spiral auditory organ (of Corti), the mammalian hearing organ.

\section{AUTHOR CONTRIBUTIONS}

BF conceived and wrote the initial draft. KE reviewed the draft and prepared the illustrations.

\section{FUNDING}

This work was supported by a grant from NIH (RO1 AG060504).

Claudius, M. (1856). Bemerkungen uber den Bau der hautigen Spiralleiste der Schnecke. Z. wiss. Zool. 7, 154-161.

Corti, A. (1851). Recherches sur l'organe de l'ouie des mammiferes. Z. Wiss. Zool. III , 3-63.

Dabdoub, A., Puligilla, C., Jones, J. M., Fritzsch, U., Cheah, X. K. S., Pevny, L. H., et al. (2008). Sox2 signaling in prosensory domain specification and subsequent hair cell differentiation in the developing cochlea. Proc. Natl. Acad. Sci. U.S.A. 105, 18396-18401. doi: 10.1073/pnas.0808175105

De No, R. L. (1981). The Primary Acoustic Nuclei. Newark, NJ: Raven Press.

Deiters, O. (1860). Beitrage zur Kenntniss der Lamina spiralis membranacea der Schnecke. Z. Wissensch. Zool. 10, 1-14.

Dewey, J. B., Xia, A., Müller, U., Belyantseva, I. A., Applegate, B. E., and Oghalai, J. S. (2018). Mammalian auditory hair cell bundle stiffness affects frequency tuning by increasing coupling along the length of the cochlea. Cell Rep. 23, 2915-2927. doi: 10.1016/j.celrep.2018.05.024

Druckenbrod, N. R., and Goodrich, L. V. (2015). Sequential retraction segregates SGN processes during target selection in the cochlea. J. Neurosci. 35, 16221-16235. doi: 10.1523/JNEUROSCI.2236-15.2015

Duverney, G. (1730). Traité de l'Organe de l'Oüe. Paris. English Ed. 76, 83-104.

Elliott, K. L., Fritzsch, B., and Duncan, J. S. (2018). Evolutionary and developmental biology provide insights intot he regeneration of organ of corti hair cells. Front. Cell. Neurosci. 12:252. doi: 10.3389/fncel.2018.00252 
Ellwanger, D. C., Scheibinger, M., Dumont, R. A., Barr-Gillespie, P. G., and Heller, S. (2018). Transcriptional dynamics of hair-bundle morphogenesis revealed with cell trails. Cell Rep. 23, 2901-2914. doi: 10.1016/j.celrep.2018. 05.002

Engström, H., Ades, H. W., and Hawkins, J. E. (1964). Cytoarchitecture of the organ of Corti. Acta Otolaryngol. 57, 92-99. doi: 10.3109/00016486409134545

FIPAT (2017). Terminologia Neuroanatomica. Halifax, NS: FIPAT.

Fritzsch, B., Dillard, M., Lavado, A., Harvey, N. L., and Jahan, I. (2010). Canal cristae growth and fiber extension to the outer hair cells of the mouse ear require Proxl activity. PLoS One 5:e9377. doi: 10.1371/journal.pone.0009377

Fritzsch, B., Kersigo, J., Yang, T., Jahan, I., and Pan, N. (2016). "Neurotrophic factor function during ear development: expression changes define critical phases for neuronal viability," in The Primary Auditory Neurons of the Mammalian Cochlea, eds A. Dabdoub, B. Fritzsch, A. N. Popper, and R. R. Fay (New York, NY: Springer), 49-84.

Goodrich, L. V. (2016). Early Development of the Spiral Ganglion, The Primary Auditory Neurons of the Mammalian Cochlea. Berlin: Springer, 11-48.

Groves, A. K., and Fekete, D. M. (2012). Shaping sound in space: the regulation of inner ear patterning. Development 139, 245-257. doi: 10.1242/dev.067074

Groves, A. K., and Fekete, D. M. (2017). "New directions in cochlear development," in Understanding the Cochlea, Vol. 62, eds G. Manley, A. Gummer, A. Popper, and R. Fay (Cham: Springer), 33-73. doi: 10.1007/978-3-319-52073-5_3

Held, H. (1893). Die centrale Gehörleitung, Arch. Anat. Physiol; Anatomische Abteilung. Frankfurt: Universitätsbibliothek Johann Christian Senckenberg, 201-248.

Held, H. (1902). Untersuchungen über den feineren Bau des Ohrlabyrinthes der Wirbeltier. Leipzig: BG Teubner.

Held, H. (1926). Die Cochlea der Säuger und der Vögel, ihre Entwicklung und ihr Bau, Receptionsorgane I. Berlin: Springer, 467-534.

Helmholtz, H. V. (1859). Ueber die Klangfarbe der Vocale. Annalen Physik 184, 280-290. doi: 10.1002/andp.18591841004

Hensen, V. (1863). Zur Morphologie der Schnecke des Menschen und der Saugetiere. Z. Wiss. Zool. 13, 481-512.

Hudspeth, A. J. (1989). How the ear's works work. Nature 341:397. doi: 10.1038/ $341397 \mathrm{a} 0$

Jahan, I., Elliott, K. L., and Fritzsch, B. (2018). Understanding molecular evolution and development of the organ of Corti can provide clues for hearing restoration. Integr. Comp. Biol. 58, 351-365. doi: 10.1093/icb/icy019

Jahan, I., Pan, N., Elliott, K. L., and Fritzsch, B. (2015). The quest for restoring hearing: understanding ear development more completely. Bioessays 37, 1016-1027. doi: 10.1002/bies.201500044

Kimura, R. S. (1975). The Ultrastructure of the Organ of Corti1, International Review of Cytology. Amsterdam: Elsevier, 173-222.

Kölliker, A. (1852). Mikroskopische Anatomie, Bd. II, S. 409. Leipzig: Universität Basel.

Kölliker, A. (1867). Handbuch der Gewebelehre des Menschen: Für Aerzte und Studirende. Leipzig: Wilhelm Engelmann.

Lewis, E. R., Leverenz, E. L., and Bialek, W. S. (1985). The Vertebrate Inner ear. Boca Raton, FL: CRC PressI Llc.

Lim, D. J. (1986). Functional structure of the organ of Corti: a review. Hear. Res. 22, 117-146. doi: 10.1016/0378-5955(86)90089-4

Liu, C., Glowatzki, E., and Fuchs, P. A. (2015). Unmyelinated type II afferent neurons report cochlear damage. Proc. Natl. Acad. Sci. U.S.A. 112, 14723-14727. doi: $10.1073 /$ pnas. 1515228112

Liu, H., Pecka, J. L., Zhang, Q., Soukup, G. A., Beisel, K. W., and He, D. Z. (2014). Characterization of transcriptomes of cochlear inner and outer hair cells. J. Neurosci. 34, 11085-11095. doi: 10.1523/JNEUROSCI.1690-14.2014

Lustig, L., Jackler, R. R. K., and Mandelcorn, R. (1998). The history of otology through its eponyms I: anatomy. Otol. Neurotol. 19, 371-389.

Mach, E. (1865a). Bemerkungen über den Raumsinn des Ohres. Annalen Physik 202, 331-333. doi: 10.1002/andp.18652021010

Mach, E. (1865b). Zwei Populäre Vorlesungen über Musikalische Akustik. Leipzig: Leuschner \& Lubensky.

Matei, V., Pauley, S., Kaing, S., Rowitch, D., Beisel, K., Morris, K., et al. (2005). Smaller inner ear sensory epithelia in Neurog1 null mice are related to earlier hair cell cycle exit. Dev. Dyn. 234, 633-650. doi: 10.1002/dvdy.20551

Merchan-Perez, A., and Liberman, M. C. (1996). Ultrastructural differences among afferent synapses on cochlear hair cells: correlations with spontaneous discharge rate. J. Comp. Neurol. 371, 208-221. doi: 10.1002/(SICI)1096-9861(19960722) 371:2<208::AID-CNE2>3.0.CO;2-6

Mudry, A. (2001). The origin of eponyms used in cochlear anatomy. Otol. Neurotol. 22, 258-263. doi: 10.1097/00129492-200103000-00024

Petitpré, C., Wu, H., Sharma, A., Tokarska, A., Fontanet, P., Wang, Y., et al. (2018). Neuronal heterogeneity and stereotyped connectivity in the auditory afferent system. Nat. Commun. 9:3691. doi: 10.1038/s41467-018-06033-3

Politzer, A. (1907). Geschichte der Ohrenheilkunde. Stuttgart: Eke Verlag.

Politzer, A. (1981). History of Otology: From Earliest Times to the Middle of the Nineteenth Century. Ann Arbor, MI: Columella Press.

Reissner, E. (1851). De Auris Internae Formatione: Dissertatio Inauguralis: Accedit Tabula Lithographica. Tartu: Dorpati Livonorum Laakmann.

Ren, T., He, W., and Kemp, D. (2016). Reticular lamina and basilar membrane vibrations in living mouse cochleae. Proc. Natl. Acad. Sci. U.S.A. 113, 9910-9915. doi: 10.1073/pnas.1607428113

Retzius, G. (1881). Das Gehörorgan der Wirbelthiere: Morphologisch-Histologische Studien. 1, Das Gehörorgan der Fische und Amphibien. Stockholm: Samson \& Wallin in Commission.

Retzius, G. (1884). Das Gehörorgan der Wirbelthiere: Morphologisch-Histologische Studien. 2, Das Gehörorgan der Reptilien, der Vögel und der Säugethiere. Stockholm: Samson \& Wallin in Commission.

Rubel, E. W., and Fritzsch, B. (2002). Auditory system development: primary auditory neurons and their targets. Annu. Rev. Neurosci. 25, 51-101. doi: 10. 1146/annurev.neuro.25.112701.142849

Rutherford, M. A., and Moser, T. (2016). The ribbon synapse between type I spiral ganglion neurons and inner hair cells. Prim. Audit. Neurons Mamm. Cochlea 52, 117-156. doi: 10.1007/978-1-4939-3031-9 5

Scarpa, A. (1800). Anatomische Untersuchungen des Gehörs und Geruchs. Aus dem Lat. Nürnberg: Verlag.

Shrestha, B. R., Chia, C., Wu, L., Kujawa, S. G., Liberman, M. C., and Goodrich, L. V. (2018). Sensory neuron diversity in the inner ear is shaped by activity. Cell 174, 1229-1246. doi: 10.1016/j.cell.2018.07.007

Simmons, D., Duncan, J., de Caprona, D. C., and Fritzsch, B. (2011). Development of the Inner ear Efferent System, Auditory and Vestibular Efferents. Berlin: Springer, 187-216. doi: 10.1007/978-1-4419-7070-1_7

Slepecky, N. B. (1996). Structure of the Mammalian Cochlea, The Cochlea. Berlin: Springer, 44-129.

Spoendlin, H. (1971). Degeneration behaviour of the cochlear nerve. Arch. klinische Exp. Ohren 200, 275-291. doi: 10.1007/BF00373310

Sun, S., Babola, T., Pregernig, G., So, K. S., Nguyen, M., Su, S. M., et al. (2018). Hair cell mechanotransduction regulates spontaneous activity and spiral ganglion subtype specification in the auditory system. Cell 174, 1247-1263. doi: 10.1016/ j.cell.2018.07.008

Von Bartheld, C. S., Patterson, S. L., Heuer, J. G., Wheeler, E. F., Bothwell, M., and Rubel, E. W. (1991). Expression of nerve growth factor (NGF) receptors in the developing inner ear of chick and rat. Development 113, 455-470.

von Sömmerring, S. T. (1806). Abbildungen des Menschlichen Hörorgans. Wenner: Varrentrapp u.

Willis, T. (1672). De Anima Brutorum Quae Hominis Vitalis ac Sensitiva Est, Exercitationes Duae. Davis, CA: E Theatro Sheldoniano, impensis Ric.

Xia, A., Udagawa, T., Raphael, P. D., Cheng, A. G., Steele, C. R., Applegate, B. E., et al. (2018). "Basilar membrane vibration after targeted removal of the third row of OHCs and Deiters cells," in AIP Conference Proceedings, AIP Publishing, (Hamburg), 020004.

Zheng, J., Shen, W., He, D. Z., Long, K. B., Madison, L. D., and Dallos, P. (2000). Prestin is the motor protein of cochlear outer hair cells. Nature 405:149. doi: $10.1038 / 35012009$

Conflict of Interest Statement: The authors declare that the research was conducted in the absence of any commercial or financial relationships that could be construed as a potential conflict of interest.

Copyright (c) 2018 Fritzsch and Elliott. This is an open-access article distributed under the terms of the Creative Commons Attribution License (CC BY). The use, distribution or reproduction in other forums is permitted, provided the original author(s) and the copyright owner(s) are credited and that the original publication in this journal is cited, in accordance with accepted academic practice. No use, distribution or reproduction is permitted which does not comply with these terms. 